\title{
ЛОГІСТИЧНИЙ ПІДХІД ДО ОРГАНІЗАЦІЇ ВАНТАЖНИХ ПЕРЕВЕЗЕНЬ ЗАЛІЗНИЧНИМ ТРАНСПОРТОМ
}

\author{
Громова О.В., к.е.н., доцент, \\ Петриковець Ю.І., магістр (УкрДУЗТ)
}

У статті розглядається питання застосування логістики при організащіі вантажних перевезень залізничним транспортом. Визначено роль, принциии та функиіі логістичного підходу до організаиії перевезень вантажів залізничним транспортом. Розглянуто питання узгодженої роботи транспорту та комериійних служб. Основну увагу приділено впровадженню логістики при розробиі ефективних транспортних маршрутів. Запропоновано шляхи впровадження логістичних підходів у комериійну роботу залізничної галузі.

Ключові слова: логістика, залізничниця, вантажнні перевезення, транспорт, послуги, комерційні перевезення.

\section{ЛОГИСТИЧЕСКИЙ ПОДХОД К ОРГАНИЗАЦИИ ГРУЗОВЫХ ПЕРЕВОЗОК ЖЕЛЕЗНОДОРОЖНЫМ ТРАНСПОРТОМ}

\author{
Громова Е.В. к.э.н., доцент, \\ Петриковец Ю.И. магистр (УкрГУЖТ)
}

В статье рассматривается вопрос применения логистики при организаџии грузовых перевозок железнодорожным транспортом. Определены роль, принщипь и функции логистического подхода к организации перевозок грузов железнодорожным транспортом. Рассмотрень вопросы согласованной работь транспорта $u$ коммерческих служб. Основное внимание уделено внедрению логистики при разработке эффрективных транспортных маршрутов. Предложены пути внедрения логистических подходов в коммерческую работу железнодорожной отрасли.

Ключевые слова: логистика, железная дорога, грузовые перевозки, транспорт, услуги, коммерческие перевозки.

\section{LOGISTIC APPROACH TO THE ORGANIZATION OF FREIGHT BY RAILWAY TRANSPORT}

\author{
Gromova O.V., Candidate of Economic Sciences, associate professor, \\ Petrikovets Y.I., master (USURT)
}

The transport component is one of the most important factors of social production and the national economy as a whole. In the conditions of market relations there is a sharp complication of functions of management of transportation processes. Today, the work of the industry should be not only in the implementation of transportation of goods. The logistics approach makes it possible to comprehensively consider the entire chain from the supply of raw materials to production to the delivery of finished products to the recipient. Therefore, the purpose of the article is to reveal the role and basic functions and principles of logistics in the implementation of freight transport by rail.

(C) Громова О.В.,

Вісник економіки транспорту і промисловості № 64, 2018

Петриковець Ю.І. 
In the transport industry, logistics is considered as the movement of goods from one point to another on the optimal route. The development of transport infrastructure contributes to the increase in the number of material flows that require the organization of a conducting level of management and optimization. Commercial structures for the purchase and sale of products for industrial purposes affect the re-process, because it is the largest share in the volume of cargo transportation by different modes of transport. The largest share of freight traffic in the sphere of trade is carried out in conjunction with commercial services that provide production needs. In this regard, we need a coordinated work of transport and commercial services, which would create conditions for timely and uniform transportation. Effective work of the industry is based on the principles of formation and application of organizational and managerial mechanism of coordination of actions of specialists of various services and complex consideration of the movement of material flows from source to consumer.

The article describes the main ways of implementation of logistics approaches in the industry. The main attention is paid to the implementation of logistics in the development of effective transport routes. The ways of implementation of logistics approaches in the commercial work of the railway industry.

Key words: logistics, railway, freight transportation, transport, services, commercial transportation.

Постановка проблеми. Транспорт $\epsilon$ найважливішим елементом системи руху товару, що забезпечує існування матеріального потоку. Він являє собою одну 3 найскладніших структур , що характеризується безліччю взаємопов'язаних параметрів. Транспортна складова $\epsilon$ одним 3 найважливіших чинників суспільного виробництва, основна функція якого полягає в разі потреби надавати транспортні послуги населенню та галузям економіки в перевезеннях.

В умовах ринкових відносин відбувається різке ускладнення функцій управління перевізними процесами. Якщо раніше основна задача залізниці була пов'язана виключно з перевезеннями, то сьогодні робота галузі полягає не тільки у здійсненні транспортного обслуговування на основі раціонального використання матеріально-технічної бази залізниці. Ринок дає можливість до вільного вибору клієнтом альтернативного виду транспорту, вибору перевізника та укладання умов перевезень згідно зі встановленими законодавством правилами. У роботі галузі при вирішенні даних проблем приймати управлінські рішення допомагає використання основних положень та засад логістики.
Зарубіжні вчені логістикою називають науку, яка вивчає оптимізацію господарських зв'язків і вирішує проблеми перевезення пасажирів та вантажів. Це молода наука, яка дає можливість знайти відповіді на важливі питання зі створення алгоритмів перевезень, вирішувати транспортні задачі, надає можливості до розроблення нових маршрутів, проводить пошук постачальників та споживачів продукції транспорту.

\section{Аналіз останніх публікацій.}

Автори ряду публікацій розглядають логістику, передусім, як науку, що дає змогу оптимізувати кооперативні зв'язки. Інші (Є. Крикавська, К. Кальченко) вважають основним середовищем застосування логістики внутрішньовиробничі процеси 3 обов'язковим включенням питань планування завантаження обладнання, визначення розмірів партій випуску деталей[2].

Вчені-транспортники вважають, що логістичну науку можна застосовувати не тільки на підприємствах транспортної галузі, але й у роботі залізничного транспорту. Внесок у вивчення питання застосування логістики у транспортній галузі під час формування ланцюгів постачання різних ресурсів, при

Вісник економіки транспорту і промисловості № 64, 2018 
плануванні транспортних маршрутів було зроблено відомими українськими вченими

- I. Аксьоновим, Ю. Кулаєвим, Ю. Пащенком, В. Щелкуновим, Л. Чернюк, О. Д. Омельченко, Ю. В. Пономарьовою, О. М. Тридід, та ін. [3, 8].

Виділення невирішених раніше частин загальної проблеми. Методика проведення будь-якого дослідження та формулювання висновків, які $\epsilon$ результатом роботи, значною мірою залежать від виваженості й досконалості розроблених наукових понять, якими оперує наука. Логістикою у наукових джерелах називають науку про просування товарів та послуг на ринку збуту. У транспортній галузі логістику розглядають як переміщення вантажів із однієї точки в іншу за оптимальним маршрутом $[1,2]$.

Мета статmі та завдання. Метою статті $\epsilon$ виявлення особливостей організації вантажоперевезень на основі логістичного підходу, що дозволяє отримати конкурентні переваги, істотно підвищити якість надання логістичних послуг та знизити витрати учасників ланцюга поставок. Ставиться завдання аналізу та оцінки використання логістичних підходів до перевезення вантажів залізничним транспортом.

Виклад основного матеріалу. В умовах глобального ринку відбувається переорієнтація та усвідомлення нових потреб у транспортно-логістичних системах. Застосування логістичного підходу, в тому числі, до процесу перевезення, дозволяє знівелювати витрати обігу, пов'язані 3 рухом матеріальних потоків. В умовах нестабільної економічної ситуації, падіння курсу національної валюти, спостерігається зростання цін на товари народного споживання, в зв'язку з чим, актуальним стає використання логістики як інструменту, що дозволяє істотно знизити витрати на транспортування товару.

У сфері товарообороту логістика містить і розглядає різні стадії і операції транспортування як єдине ціле. Комплексний підхід до системи логістики транспорту здійснюється

задля ритмічного, своєчасного i якісного забезпечення споживачів товарами, замовників - послугами зі скороченнями витрат як споживачів, замовників, так i взаємодіючих 3 ними інших суб'єктів ринків товарів і послуг.

В наш час широке використання логістики в господарській діяльності зумовлене необхідністю скорочення часових інтервалів між пошуком сировинних джерел й постачанням товарів кінцевому споживачеві, а також зменшенням часу реалізації товару, часу простоїв під вантажними та технічними операціями. Логістика дозволяє мінімізувати товарні запаси або взагалі відмовитись від їх використання, дає можливість до скорочення часу доставки товарів від постачальника до споживача прямим шляхом, прискорює процес отримання інформації, підвищує рівень сервісу, а в кінцевому результаті - економія витрат на здійснення перевізного процесу та роботи всісї інфраструктури [1].

Логістична діяльність - це інтеграція процесу від виготовлення продукції до доставки споживачу, що включає в себе вантажнорозвантажувальні операції, зберігання i транспортування товарів, а також необхідні інформаційні процеси, використовує процес планування, реалізації i контролю ефективних та економних 3 огляду на витрати переміщення та зберігання матеріалів, напівфабрикатів i готової продукції, a також одержання інформації про постачання товарів від місця виробництва до місця споживання згідно 3 вимогами клієнтури [2]. Усі вищеназвані операції входять до спектру послуг транспортного обслуговування споживачів і створюють умови до розвитку активної комерційної діяльності.

Наприклад, аналізуючи динаміку вантажообігу з 2010 по 2013 рр., можна відзначити, що за всіма видами транспорту цей показник залишився на одному рівні, а з 2013 по 2016 рр. спостерігався спад, окрім 
автомобільного транспорту. Однак, що потребує застосування логістичного порівнюючи показники між різними підходу планування вантажних перевезень видами транспорту (табл. 1)[7], можна 3 метою зменшення транспортної констатувати, що по залізничному складової у собівартості перевезеної транспорту він склав 187,6 млрд т-км у продукції. 2016 р. проти 212,1 млрд т-км у 2010 році,

Таблиия 1

Вантажообіг за видами транспорту, (млрд.ткм)

\begin{tabular}{|c|c|c|c|c|c|c|c|}
\hline & 2010 & 2011 & 2012 & 2013 & 2014 & 2015 & 2016 \\
\hline Транспорт & 411,1 & 437,9 & 405,9 & 393,3 & 353,6 & 334,7 & 344,2 \\
\hline Залізничний & 212,1 & 237,7 & 232,4 & 219,5 & 210,2 & 195,1 & 187,6 \\
\hline Морський & 5,0 & 4,9 & 3,5 & 3,2 & 4,1 & 3,9 & 2,5 \\
\hline Річковий & 3,8 & 2,2 & 1,7 & 1,4 & 1,3 & 1,6 & 1,5 \\
\hline Автомобільний & 52,8 & 56,3 & 56,4 & 57,4 & 56,0 & 53,3 & 58,0 \\
\hline Авіаційний & 0,4 & 0,4 & 0,4 & 0,3 & 0,2 & 0,2 & 0,2 \\
\hline Трубопровідний & 137,0 & 136,5 & 111,5 & 111,4 & 81,8 & 80,7 & 94,4 \\
\hline
\end{tabular}

Комплексний підхід застосування логістики в управлінні матеріальними та інформаційними потоками в межах системи повинно включати такі принципи:

1) комплексний розгляд руху матеріальних потоків від первинного джерела до кінцевого споживача, що передбачає виконання таких видів діяльності, як транспортування, завантаження, розвантаження, переміщення, складування і зберігання матеріалів;

2) формування і застосовування організаційно-управлінського механізму координації дій спеціалістів різних служб, які беруть участь в управлінні матеріальними потоками. Адже від успішного ув'язання комплексу заходів щодо оптимізації розміру замовлень і рівня запасів, вибору найвигідніших маршрутів, переміщення матеріалів, удосконалення складування та інших операцій буде залежати результативність роботи [2].

3 розвитком зовнішньоекономічної діяльності України з'явилися нові вимоги до залізничної галузі, такі як розбудова міжнародних транспортних магістралей, удосконалення існуючих законодавчих норм та законів щодо проведення міжнародної комерційної роботи. Для цього необхідно створити привабливі інвестиційні та партнерські умови, щоб залучити якомога більше іноземних інвесторів та партнерів.

Для забезпечення гнучкої, орієнтованої на споживача логістичної системи необхідно, щоб фізична система функціонувала паралельно інформаційній системі.

Логістична інформаційна система повинна функціонувати відповідно до цілей і завдань оптимального управління матеріальними і супутніми їм потоками, причому ці завдання мають бути об'єднані як внутрішніми цілями організації товаропотоку, так і зовнішніми.

Застосування принципів логістики при організації вантажних перевезень $\epsilon$ важливим етапом визначення основних шляхів впровадження даного механізму в роботу галузі, які повинні включати:

- системний підхід до організації матеріальних потоків на рівні галузі, підприємств та його підрозділів;

- можливість обліку та аналізу витрат протягом усього логістичного ланцюга під час виробничої діяльності галузі;

- технічне оснащення, яке б відповідало поставленим;

Вісник економіки транспорту і промисловості № 64, 2018 
- залучення професійноорієнтованого персоналу, забезпечення безпечних та комфортних умов праці;

$$
\text { - } \quad \text { відповідне }
$$

сервісне

обслуговування клієнтів;

- здатність адаптування до умов ринку.

3 метою об'єктивної оцінки потенціалу транспортної галузі доцільно проводити аналіз іiі сильних та слабких сторін - SWOT-аналіз. Він дає можливість для оцінки переваг та недоліків залізничної галузі 3 метою використання переважаючих факторів як інструменту, який здатен підвищити конкурентоспроможність залізниці вище, ніж потенційні можливості його транспортних конкурентів[10].

Згідно 3 ранжируванням, значна перевага належить залізничному транспорту, який задовольняє потреби клієнтів 3 мінімальними витратами при максимальній оптимізації роботи.

Концепція розвитку комплексного логістичного управління транспортуванням обгрунтовується таким чином: фактичне переміщення товарів у процесі обігу, яке здійснюється шляхом їх транспортування, забезпечується системою комерційно-посередницьких організацій i комерційних служб підприємств. Комерційна діяльність залізниці, яка сьогодні грунтується на принципах логістики та менеджменту, розвивається відповідно до вимог ринку.

За допомогою логістичного підходу, визначення послідовності проходження продукції через пункти складування із подальшим розміщенням іiі у складських приміщеннях стає більш спрощеним, що $\epsilon$ на користь галузі i iï клієнтам. Залучення до роботи новітніх технологічних розробок та досягнень дають можливість до оперативного регулювання поставок та перевезень 3 найменшими втратами часу і матеріальних ресурсів, дають можливість до розвитку та модернізації складського господарства.

Комерційні структури із закупівлі і продажу продукції виробничо-технічного призначення впливають на перевізний процес, оскільки він становить найбільшу частку в обсязі вантажних перевезень різними видами транспорту. Найбільша частка вантажних перевезень у сфері товарообігу виконується спільно 3 комерційними службами, забезпечуючими виробничі потреби.

Вони визначають не тільки обсяги, напрями i чергові вантажопотоки, а й створюють необхідні умови для раціонального використання логістики, яка оптимізує транспортування продукції i удосконалює складські операції. У свою чергу, транспорт впливає на кількість характеристик i показників комерційної діяльності. Регулярність вантажних перевезень впливає на своєчасність поставок продукції. I разом 3 тим, порушення ритму роботи транспортних організацій збільшує розміри запасів продукції, додаткові складські і транспортні витрати, число невиконання постачань, простого виробничого обладнання.

У зв'язку з цим потрібна узгоджена робота транспорту i комерційних служб, яка б створювала умови своєчасних i рівномірних перевезень. Зниження собівартості перевезень створює визначальні умови для відносного зниження транспортних тарифів i, як слідство, призводить до скорочення рівня останніх. Тому комерційно-посередницькі та інші комерційні служби, забезпечуючи зниження витрат обігу, мають бути зацікавлені у скороченні витрат i транспортних організацій. Під впливом змін у запасах продукції залежно від розміру розміщення транспортних засобів формується кількість одноразових постачальників[5].

Ефективні господарські зв'язки, які укладаються між контрагентами, розвиваються при умові надання галуззю комерційних і транспортно-експедиційних послуг i бажано одним пакетом. Це дозволяє використання досягнень логістики при наданні транспортноекспедиційних послуг, що $є$ запорукою 
підвищення ефективності вітчизняного транспортного комплексу й активізації його інтеграції у світову транспортну систему.

При вирішенні проблем, пов'язаних iз розвитком транспортної галузі в сьогоднішніх умовах господарювання, все частіше використовують проведення аналізу логістичних систем, що включає у себе процес дослідження та формування даних систем будь-якого економічного об'єкта. Суть методу аналізу полягає в максимально можливому спрощенні складної проблеми, яку необхідно вирішити. Такі завдання аналізують i перетворюють на серію простих задач, що мають аналоги розв'язання у більш успішних галузях. При цьому відбувається пошук ефективних важелів управління складними логістичними об'єктами галузі.

Механізм застосування даного підходу при плануванні вантажних перевезень 3 метою спрощення вироблення управлінського рішення або вирішення складних задач повинен полягати в такому[8]:

1. Поставлену задачу можна розділити на прості складові, які можна легко вирішити.

2. Проводиться підбір i застосування у плануванні найбільш прийнятних спеціальних методів логістики для вирішення окремих задач.

3. Конкретні рішення окремих задач складаються у єдину систему, яка окреслює пошук вирішення глобальної проблеми.

Для здійснення даних етапів потрібні певні заходи зі збору конкретної інформації про об'єкт, що досліджується, при цьому розробляються декілька варіантів вирішення проблеми або формування плану перевезень.

При плануванні вантажних перевезень важливо визначити за допомогою розрахунків та методів прогнозування конкретні основні експлуатаційні показники функціонування галузі 3 метою виявлення найбільш негативних явищ у роботі. Правильно проведений аналіз розрахунків дає можливість передбачити подальший розвиток об'єкта, заздалегідь окреслити можливі фактори впливу на об'єкт, розробити систему запобігання негативним наслідкам у випадках невиконання плану[9].

Висновки. Отже, застосовуючи логістичний підхід до організації вантажних перевезень залізничним транспортом можливо зробити весь комплекс дій від постачання сировини на виробництво продукції до доставки готового товару одержувачу більш спрощеним та економічно вигідним. Залучення новітніх технологічних розробок та досягнень дають можливість оперативного регулювання поставок та перевезень 3 найменшими втратами часу $\mathrm{i}$ матеріальних ресурсів, дають можливість до розвитку та модернізації складського господарства, адже у залізничній галузі існує потреба у пошуку шляхів досягнення зниження витрат, оскільки засоби та ресурси для досягнення цілей галузі $\epsilon$ обмеженими.

Сучасні методи підвищення ефективності управління матеріальними потоками мають практичний інтерес для української економіки, їх використання дасть можливість підприємствам нашої країни ефективно діяти як на внутрішньому, так i на зовнішньому ринках, підвищити рівень сервісного обслуговування конкурентоспроможності вітчизняної продукції.

\section{ПЕРЕЛІК ВИКОРИСТАНИХ ДЖЕРЕЛ}

1. Горяїнов, О. М. Практика вантажних перевезень і логістики : навч. посіб. / О. М. Горяїнов. -Х.: Вид-во «Кортес-2001», 2008. - 323 с.

2. Крикавська, Є. Логістика - нова філософія управління / Є. Крикавська // Податкове планування. - 2002. - № 5. - С. 28-31

3. Основи економіки транспорту : підручник / В. І. Щелкунов, Ю. Ф. Кулаєв, 
Л. Г. Зайончик та ін. - К. : Кондор, 2011. 392 c.

4. Орловська, О. В. Комплексний розвиток продуктивних сил Карпатського регіону / дис. ... канд. ек. наук: 08.00.05 К., 2007. - 148 c.

5. Таньков, К. М. Виробнича логістика : навч. посіб. / К. М. Таньков, О. М. Тридід, Т. О. Колодязєва. - Х. : ВД «IНЖЕК», 2004. - 352 c.

6. Николаева, М. А. Товароведение потребительских товаров. Теоретические основы : учеб. для вузов / М. А. Николаева. - M. : HOPMA, 2000. -283 c.

7. Транспорт і зв'язок України -2012 : статистичний зб. - К., 2013. - 269 с.

DOI 10.18664/338.47:338.45.v0i64.149570
8. Омельченко, О. Д. Створення логістичної системи керування вантажопотоками на залізничному транспорті [Текст] / О. Д. Омельченко,С. О. Артем-чук // Зб. наук. пр. ДЕТУТ. Сер. Транспортні системи і технології. - 2007. Вип. 12. - С. 141-145.

9. Пономарьова, Ю. В. Логістика [Текст]: навч. посіб. / Ю. В. Пономарьова. К.: Центр навчальної літератури, 2003. $192 \mathrm{c}$.

10. Тридід, О. М. Логістика [Текст]: навч. посіб. / О. М. Тридід.- К. : Знання, 2008. - 566 с

УДК 656.2.001.73(477)

\title{
СТАН І ОНОВЛЕННЯ РУХОМОГО СКЛАДУ В УМОВАХ РЕФОРМУВАННЯ УКРЗАЛІЗНИЦ
}

\author{
Єлагін Ю.В., к.е.н., доцент, \\ Глущенко Ю.В., махістр, \\ Цапко Л.В., магістр (УкрДУЗТ)
}

Визначено поточний стан рухомого складу та особливості різних напрямів його оновлення. Набагато більшою проблемою порівняно з дефіцитом вагонів являється дефіцит локомотивів. Прискорене оновлення та поповнення тягового рухомого складумпотрібно усім ключовим галузям економіки Украӥни. Для иього потрібна участь в оновленні локомотивного парку приватних операторів перевізників.

Ключові слова: локомотиви,оновлення тягового рухомого складу

\section{СОСТОЯНИЕ И ОБНОВЛЕНИЕ ПОДВИЖНОГО СОСТАВА В УСЛОВИЯХ РЕФОРМИРОВАНИЯ УКРЗАЛИЗНЫЦИ}

\author{
Елагин Ю.В., к.э.н., доцент, \\ Глущенко Ю.В., магистр, \\ Цапко Л.В., магистр (УкрГУЖТ)
}

Рассмотрено текущее состояние подвижного состава и основные особенности разных направлений его обновления. Намного большей проблемой сравнительно с дефицитом вагонов является дефицит локомотивов. Ускоренное обновление и пополнение тягового подвижного состава, необходимо всем ключевым отраслям 